7. Osvitniy transformer: Finliandiya yak natkhnennia [Educational transformer: Finland as inspiration]. Retrieved from: http:// education-ua.org/ru/porivnyalna-pedagogika/1104-osvitnij transformer-finlyandiya-yak-natkhnennya [in Ukrainian].

8. Pedahohika partnerstva: polskyi, kanadskyi, nimeckyi ta ukrayinskyi dosvid [Cooperative pedagogy: Polish, Canadian, German and Ukrainian experience]. Retrieved from: https://osvitoria.media/experience/pedagogika-partnerstva-polskyj-kanadskyjnimetskyj-ta-ukrayinskyj-dosvid/ [in Ukrainian].

9. Pedahohika partnerstva: polskyi dosvid spilkuvannia vchyteliv z batkiamy [Cooperative pedagogy: Polish experience of teachersparents communication]. Retrieved from: http://rivne1.tv/Info/?id=85655 [in Ukrainian].

10. Pedahohika spivrobitnictva: sutnist, kliuchovi ideyi, formy ta metody [Cooperative pedagogy: essence, key ideas, forms and methods]. Retrieved from: http://osvita.ua/school/lessons_summary/upbring/31097/ [in Ukrainian].

\title{
Shevchuk H. Y. Pedagogy of partnership in Ukraine: establishment and development
}

The article provides main foundations of the partnership pedagogy as one of the main ideas of the New Ukrainian School concept, the mission of which is to develop abilities, talents and possibilities of every child. Partnership pedagogy becomes important as a vector of humane and creative approach to every participant of the educational process.

The process of the partnership pedagogy formation in Ukraine is analyzed, foreign experience of its formation is investigated and examples of the effective impact of partnership pedagogy in individual countries are presented. The principles, methodological approaches and ways of its implementation in modern conditions of secondary education reforming are revealed. It is stated that the partnership pedagogy every year proves its need to achieve the main goal of the modern world - creation of a new humane society. Emphasis is placed on the successful implementation of the humanistic principle at the educational establishment, under the conditions of the priority values recognition of the teacher and students'personality, the change of the teacher position, who must always adhere to a personally-oriented approach in teaching and upbringing. Personally oriented approach is the embodiment of the humanistic pedagogy. Because it outlines the idea of a new perspective on personality as a goal of education. Today, it is a harmonious development of the child's personality, and partnership is the main category of education and training, where educators and pupils are equal subjects of the educational process, who have freedom and equal conditions of choice. The main task of school is to develop a child so that he/she, without compulsion, could and would like to acquire knowledge, skills and develop abilities. The new orientation of education is formed under the influence of social, theoretical and educational factors. However, the teacher must firstly teach himself to think complexly, combining in his work all the available ways to achieve goals and fulfil the set tasks.

Key words: pedagogy of partnership, New Ukrainian School, humanism, learner-centred approach, secondary education reform, students, parents, teachers.

УДК 372.881.111.1

DOI https://doi.org/10.31392/NPU-nc.series5.2019.71.63

Якименко П. В.

\section{ПІДГОТОВКА МАЙБУТНІХ УЧИТЕЛІВ ІНОЗЕМНОЇ МОВИ ДО ПРОФІЛЬНОГО НАВЧАННЯ СТАРШОКЛАСНИКІВ: ДЕФІНІТИВНИЙ АНАЛІЗ}

Актуалізується проблема підготовки майбутнього вчителя іноземної мови до профільного навчання старшокласників, теоретично досліджено наукові підходи вчених до тлумачення ключових понять «підготовка», «професійнопедагогічна підготовка майбутнього вчителя іноземної мови», «готовність до професійно-педагогічної діяльності».

У контексті проблеми дослідження поняття «підготовка майбутніх учителів іноземної мови» розглядаємо як безперервний, иілісний, системний і керований освітній процес, який забезпечує готовність студентів до професійнопедагогічної діяльності та сформованість інтегрованого особистісного утворення, щчо містить у своїи структурі мотиваційно-ціннісний, когнітивно-операційний, рефлексивний, діяльнісний, особистісний компоненти.

Важливо зазначити, щзо для характеристики поняття «професійно-педагогічна готовність» вчені використовують поняття «професійна компетентність», яке визначається як професійна готовність і здатність суб 'єкта праці до виконання завдань і обов 'язків повсякденної діяльності.

Результатом підготовки майбутніх учителів до професійної діяльності є певний рівень готовності до професійної діяльності, активно-діяльнісний стан особистості, щуо охоплює позитивне ставлення до професії, здібності, знання, вміння, навички, стійкі професійно важливі якості.

Професійна готовність майбутнього вчителя іноземної мови до педагогічної діяльності характеризується його професійною кваліфікацією та певною сукупністю особистісних якостей і властивостей.

Варто зазначити, щзо організація у закладах вищої освіти професійної підготовки майбутніх учителів іноземної мови має певні особливості, які трунтуються на інтегрованому підході до забезпечення змісту навчально-виховного проиесу.

Дефінітивний аналіз поняття «професійно-педагогічна підготовка майбутніх учителів іноземної мови» дає підстави стверджувати, щзо результатом зазначеного процесу є загальнокультурна, професійна, психолого-педагогічна, лінгвістична, методично-технологічна підготовка, щзо є важсливою умовою забезпечення якості та продуктивності реалізації освітнього, практичного та виховного компонентів профільного навчання старшокласників.

Ключові слова: майбутній учитель іноземної мови, професійно-педагогічна підготовка, професійна компетентність, готовність, професійна готовність, навчання, виховання, педагогічний процес. 
Головною метою системної трансформації освітньої галузі в Україні є нова висока якість освіти на всіх рівнях: від початкової школи - до закладів вищої освіти. У контексті зазначеного вище виникла потреба у створенні системи постійного підвищення якості професійної підготовки майбутніх учителів, яка має відповідати вимогам нової української школи до введення профільної диференціації на основі отримання єдиної базової освіти учнями. Згідно з Законами України «Про освіту», «Про вищу освіту», Стратегією інноваційного розвитку України 2009-2019 рр. та на період до 2039 р., Концепцією Нової української школи, Концепцією розвитку профільного навчання у загальноосвітніх школах України, Концепцією неперервної педагогічної освіти актуалізується проблема оновлення змісту та технологій професійної підготовки майбутнього вчителя іноземної мови до ефективного забезпечення профільної освіти учнів старшої школи.

Реформування процесу підготовки майбутніх учителів іноземної мови актуалізує наукові пошуки вчених щодо дослідження її особливостей та організації в контексті сучасних підходів до викладання іноземних мов; Науковий інтерес дослідників (А. Басіна, В. Буренко, О. Вишневський, Н. Гальскова, Н. Гез, В. Куліш, С. Ніколаєва, Є. Маслико, В. Редько, П. Сисоев, В. Яніна) становлять педагогічні, психологічні і методичні аспекти формування іншомовної комунікативної компетентності майбутніх учителів іноземної мови.

Автори О. Будник, С. Вітвицька, І. Гавриш, А. Коломієць,С. Литвиненко, Ю. Пелех, Л. Рибалко, О. Семеног, Г. Троцко активно досліджують актуальну проблему оптимізації професійної підготовки майбутнього вчителя в системі вищої освіти. Автор О. Шмирко досліджує теоретичні засади та психолого-педагогічні особливості професійного розвитку майбутніх учителів іноземної мови в системі університетської педагогічної освіти, виокремлюючи напрями організації навчально-виховного процесу, що спрямовані на професійний розвиток майбутніх учителів іноземної мови.

Метою статті є розкриття сутності поняття «підготовка», «професійно-педагогічна підготовка» та визначення співвідношення понять «професійно-педагогічна підготовка» і «готовність до професійно-педагогічної діяльності».

У «Національній доктрині розвитку освіти України у XXI столітті» зазначено, що «підготовка педагогічних працівників, їх професійне вдосконалення - важлива умова модернізації освіти» [9].

Впровадження основних положень «Концептуальних засад розвитку педагогічної освіти України та ії інтеграції в європейський освітній простір» передбачає створення такої системи педагогічної освіти, яка на основі національних надбань світового значення та усталених європейських традицій забезпечує формування педагогічних працівників, здатних здійснювати професійну діяльність на демократичних та гуманістичних засадах, реалізовувати освітню політику як пріоритетну функцію держави, що спрямовується на розвиток та самореалізацію особистості, задоволення ії освітніх і духовно-культурних потреб.

На переконання Н. Степякової «основним критерієм стану і результативності вищої педагогічної освіти є якість професійної підготовки майбутнього вчителя.

Поняття «підготовка» вчені тлумачать по-різному. Дослідниця О. Котова, пояснюючи зміст терміну «підготовка», акцентує увагу на його методичному аспекті як «сукупності засобів і методів, а також порядку їх використання в навчанні» [5].

Вчені О. Мороз та В. Сластьонін визначають зазначену вище категорію як «процес формування готовності до професійної діяльності» [10].

Поняття «професійно-педагогічна підготовка» Н. Ничкало пояснює як «частину організованого педагогічного процесу з набуття професійних знань, умінь і ціннісних установок, яка реалізується в межах відповідного циклу галузевого стандарту» [7]. На переконання В. Лозової та Г. Троцко поняття «професійно-педагогічна підготовка» $є$ компонентом метасистеми, у ролі якої виступає педагогічна система, що характеризується взаємозв'язком і взаємодією структурних та функціональних компонентів, сукупність яких забезпечує формування особистості студента та його готовність до професійної діяльності [7].

На цінносному аспекті професійно-педагогічної підготовки майбутніх учителів іноземної мови зосереджує увагу дослідник I. Ісаєв, стверджуючи, що зазначене поняття є процесом засвоєння, передачі та створення педагогічних цінностей і технологій, результатом якого є опанування майбутнім учителем іноземної мови соціокультурних цінностей (особистісні цінності людини, цінності культури спілкування державною, рідною, іноземною мовами, цінності культури особистості тощо) [3].

Таким чином, поняття «професійно-педагогічна підготовка» тлумачиться і як процес формування готовності до неї, і як формування системи установок на педагогічну діяльність, орієнтації на виконання професійних завдань, загальної готовності до праці.

У контексті проблеми дослідження поняття «підготовка майбутніх учителів іноземної мови» розглядаємо як безперервний, цілісний, системний і керований освітній процес, який забезпечує готовність студентів до професійно-педагогічної діяльності та сформованість інтегрованого особистісного утворення, що містить у своїй структурі мотиваційно-ціннісний, когнітивно-операційний, рефлексивний, діяльнісний та особистісний компоненти.

Отже, результатом підготовки майбутніх учителів до професійної діяльності є певний рівень готовності до професійної діяльності, активно-діяльнісний стан особистості, що охоплює позитивне ставлення до професії, здібності, знання, вміння, навички, стійкі професійно важливі якості. 
У сучасній науковій літературі поняття «готовність до педагогічної діяльності» розуміється вченими по-різному. На думку С. Максименко та О. Пелех, поняття «готовність» $є$ цілеспрямованим проявом особистості, що включає ії переконання, погляди, мотиви, почуття, вольові та інтелектуальні якості, знання, вміння, навички й установки [8]. Варто зазначити, що А. Ліненко розуміє зазначений вище термін «як цілісне утворення, яке характеризує емоційно-когнітивну і вольову мобілізаційність суб' єкта в момент його включення в діяльність певного спрямування» [6].

Автор Л. Рибалко тлумачить поняття «готовність» на основі акмеологічого підходу, зокрема, як «професійно-педагогічну самореалізацію майбутнього вчителя», пояснюючи зазначену вище педагогічну категорію як «особистісні інтегровані новоутворення в мисленні, свідомості, самосвідомості, якостях особистості майбутнього вчителя (інтелектуальних, психічних, фізичних та інших), які забезпечують продуктивне виконання педагогічної діяльності» [10].

За В. Шаховим «готовність майбутнього вчителя до професійної діяльності - $є$ активним станом особистості, установкою на певну поведінку, мобілізацією сил для виконання певного завдання».

Актуальною у контексті реалізації компетентнісного підходу до забезпечення якості вищої освіти в Україні $\epsilon$ позиція Л. Паламар щодо розуміння поняття «готовність», яке є результатом вироблення майбутнім педагогом моделі майбутньої педагогічної діяльності залежно від отриманих у процесі професійної підготовки знань, умінь, навичок та сформованого рівня компетентності.

У Законі України «Про вищу освіту» визначено поняття «компетентність» як «динамічна комбінація знань, вмінь і практичних навичок, способів мислення, професійних, світоглядних і громадянських якостей, морально-етичних цінностей, яка визначає здатність особи успішно здійснювати професійну та подальшу навчальну діяльність і є результатом навчання на певному рівні вищої освіти», а результати навчання - як «знання, уміння, навички, способи мислення, погляди, цінності, інші особисті якості, які можна ідентифікувати, спланувати, оцінити і виміряти та які особа здатна продемонструвати після завершення освітньої програми або окремих освітніх компонентів».

Важливо зазначити, що для характеристики поняття «професійно-педагогічна готовність» вчені використовують поняття «професійна компетентність», яке визначається як професійна готовність і здатність суб'єкта праці до виконання завдань і обов'язків повсякденної діяльності. За визначенням В. Сластьоніна, «професійна компетентність включає проблемно-практичний, смисловий та ціннісний аспекти та $є$ інтегральною характеристикою ділових і особистісних якостей спеціаліста, яка відображає рівень знань, умінь, досвіду, достатніх для досягнення цілей професійної діяльності, а також соціально-моральну позицію особистості. Різновидами професійної компетентності В. Сластьонін вважає такі: практична (спеціальна), соціальна, психологічна, інформаційна, комунікативна, екологічна, валеологічна» [10]. Згідно з А. Марковою, слід розрізняти процесуальний (педагогічна діяльність, педагогічне спілкування, особистість учителя) та результативний (навчання і навченість, виховання і вихованість) аспекти компетентності вчителя, до складників якої відносить спеціальну, особистісну, індивідуальну та екстремальну професійні компетентності [9].

Отже, професійна готовність майбутнього вчителя іноземної мови до педагогічної діяльності характеризується його професійною кваліфікацією та певною сукупністю особистісних якостей і властивостей.

Актуальною є наукова позиція О. Іваницького щодо інтеграції процесу формування готовності майбутнього вчителя іноземної мови до професійної діяльності та оволодіння ним іноземною мовою і культурами. Дослідник тлумачить зазначений вище феномен як «певний рівень володіння мовними, мовленнєвими та соціокультурними знаннями, навичками та вміннями, що дають змогу індивіду комунікативно прийнятно і доцільно варіювати власну мовну поведінку залежно від функціональних факторів одномовного, двомовного або тримовного спілкування, створюють основу для комунікативного полікультурного розвитку індивіда» [4].

У контексті проблеми дослідження значущою є наукова думка Л. Башман (L. Bachman), який вважає, що готовність учителя-філолога до педагогічної діяльності є тотожною його комунікативній компетентності, яку вчений розглядає через комунікативні мовні вміння, які характеризують такі компетенції, як-от: мовну / лінгвістичну (можливість висловлюватись іноземною мовою лише на основі засвоєних знань, розуміння мови як системи); дискурсивну (зв’язаність, логічність, організація мови); прагматичну (вміння передати комунікативний зміст відповідно до соціального контексту); розмовну (вміння говорити зв'язно, без напруги, в природньому темпі, без затяжних пауз для пошуку мовних форм); соціально-лінгвістичну (вміння вибирати мовні форми); стратегічну (вміння використовувати комунікативні стратегії для компенсації відсутніх знань в умовах реального мовного простору); мовномисленнєву (готовність до створення комунікативного змісту в результаті мовномисленнєвої діяльності: взаємодія проблеми, знань і дослідження).

Висновки. Дефінітивний аналіз поняття «професійно-педагогічна підготовка майбутніх учителів іноземної мови» дає підстави стверджувати, що результатом зазначеного процесу є загальнокультурна, професійна, психолого-педагогічна, лінгвістична, методично-технологічна підготовка, що є важливою умовою забезпечення якості та продуктивності реалізації освітнього, практичного та виховного компонентів профільного навчання старшокласників.

У перспективі за доцільне вважаємо дослідити компоненти, критерії, показники та рівні сформованості професійно-педагогічної готовності майбутнього вчителя іноземної мови до профільного навчання старшокласників. 


\section{Використана література:}

1. Гусєва Т. П. Психологічні засоби розвитку креативності майбутніх учителів філологічного профілю : автореф. дис. на здобуття наук. Ступеня канд. психол. наук : 19.00.07 «Педагогічна та вікова психологія». Київ, 2006. с. 59.

2. Исаев И. Ф. Профессионально-педагогическая культура преподавателя. Москва : Академия, 2004. 240 с.

3. Іваницький О. І. Теоретичні і методичні основи підготовки майбутнього вчителя фізики до впровадження інноваційних технологій навчання : автореф. дис. на здобуття наук. ступеня доктора пед. наук : 13.00 .02 «Теорія та методика виховання». Київ, 2005. 43 с.

4. Котова Е. В. К вопросу о современном состоянии профессиональной подготовки учителя физической культуры. Педагогіка, психологія та медикобіологічні проблеми фізичного виховання і спорту : наук. монографія. за ред. Єрмакова С. С. Харків : ХДАДМ (ХХПІ), 2007. № 6. С. 160-164.

5. Линенко А. Ф. Теория и практика формирования готовности студентов педагогических вузов к профессиональной деятельности : дис. ... доктора пед. наук: 13.00.01, 13.00.04. Київ, 1996. 378 с.

6. Лозова В. І. Теоретичні основи виховання і навчання : навч. посібник для студ. пед. навч. закладів / В. I. Лозова, Г. В. Троцко. Харків : «ОВС», 2002. 400 с.

7. Максименко С. Д. Фахівця потрібно моделювати (Наукові основи готовності випускника педвузу до педагогічної діяльності) / С. Д. Максименко, О. М. Пелех. Рідна школа. 1994. № 3/4. С. 68-72.

8. Маркова А. К. Психология профессионализма. Москва, 1996. 312 с.

9. Навчальний процес у вищій педагогічній школі : навч. посібник / О. Г. Мороз, В. О. Сластьонін та ін. Київ : НПУ ім. М. П. Драгоманова, 2001. 338 с.

10. Ничкало Н. Г. Неперервна професійна освіта як філософська та педагогічна категорія. Неперервна професійна освіта: теорія і практика. 2001. Вип. 1. С. 18-35.

1. Guseva T. P. (2006). Psihologichni zasobi rozvitku kreativnostI maybutnIh uchitelIv filologichnogo profilyu : avtoref. dis. na zdobuttya nauk. Stupenya kand. psihol. nauk : spets. 19.00.07 «Pedagogichna ta vikova psihologiya» [Psychological means of development of creativity of future teachers of philological profile: author. diss. for the sciences. Degree of Cand. psych. Sciences: 19.00.07 «Pedagogical and age psychology»], p. 59 [in Ukrainian].

2. Isaev, I. F. (2004). Professionalno-pedagogicheskaya kultura prepodavatelya [Professional-pedagogical culture of the teacher], p. 240. Moscow : Akademiya.

3. Ivanitskiy, O. I. (2005). Teoretichni i metodichni osnovi pidgotovki maybutnogo vchitelya fiziki do vprovadzhennya innovatsiynih tehnologiy navchannya : avtoref. dis. na zdobuttya nauk. stupenya doktora ped. nauk : spets. 13.00 .02 «Teorlya ta metodika vihovannya» [Theoretical and methodological bases of preparation of the future Physics teacher to introduce innovative teaching technologies: author's abstract. diss. for the sciences. degree of doctor of ped. Sciences: 13.00.02 «Theory and methodology of education»], p. 43 [in Ukrainian].

4. Kotova, E. V.(2007). K voprosu o sovremennom sostoyanii professionalnoy podgotovki uchitelya fizicheskoy kulturyi. PedagogIka, psihologIya ta medikobIologIchnI problemi fIzichnogo vihovannya I sportu: nauk. monograftya. za red. Ermakova S. S. [To the question of the current state of professional training of physical education teacher. Pedagogy, Psychology and Medico-biological Problems of Physical Education and Sport: Sciences. monograph. in a row. Yermakova S.S.]. Harkiv : HDADM (XXPI),6, pp. 160-164 [in Ukrainian].

5. Linenko, A. F. (1996). Teoriya i praktika formirovaniya gotovnosti studentov pedagogicheskih vuzov k professionalnoy deyatelnosti : dis. doktora ped. nauk: 13.00.01, 13.00.04 [Theory and practice of forming readiness of students of pedagogical universities for professional activity: dissertation. doctor ped. Sciences: 13.00.01, 13.00.04], p. 378 [in Ukrainian]

6. Lozova, V. I. \& Trotsko, G. V. (2002). TeoretichnIi osnovi vihovannya i navchannya: navch. posibnik dlya stud. ped. navch. zakladIv [Theoretical Foundations of Upbringing and Learning: Tutorial. study guide. ped. teach. institutions]. HarkIv : «OVS», p. 400 [in Ukrainian].

7. Maksimenko, S. D., Peleh, O. M. (1994). Fahivtsya potribno modelyuvati (Naukovi osnovi gotovnosti vipusknika pedvuzu do pedagogichnoyi diyalnosti). Ridna shkola. 3/4, p. 72 [in Ukrainian].

8. Markova, A. K. (1996). Psihologiya professionalizma [Psychology of professionalism], p. 312 [in Ukrainian].

9. Moroz, O. G., Slastonin V. O. (2001). Navchalniy protses u vischiy pedagogichnly shkoli : navch. posibnik [Educational process in higher pedagogical school: study. manual]. Kyiv : NPU im. M. P. Dragomanova, p. 338 [in Ukrainian].

10. Nichkalo, N. G. (2001). Neperervna profesiyna osvita yak filosofska ta pedagogichna kategoriya [Continuing professional education as a philosophical and pedagogical category]. Neperervna profesIyna osvIta: teorlya I praktika - Continuing Professional Education: Theory and Practice, Vip. 1, p. 18-35 [in Ukrainian].

Yakymenko P. V. Preparation of future teachers of a foreign language for the specific training of high school students: a definitive analysis

In the article, the author actualizes the problem of preparing the future teacher of a foreign language for the specialized education of high school students, theoretically explores the scientific approaches of scientists to the interpretation of the key concepts of "preparation», "professional and pedagogical preparation of the future teacher of foreign language», "readiness for professional and pedagogical activity».

In the context of problem's study, we consider the concept of «preparing future teachers of a foreign language» as a continuous, holistic, systemic and manageable educational process that ensures students are ready for professional and pedagogical activity and the formation of integrated personal education, containing in its structure motivational-value, cognitive-operational, reflective, active, personality components.

It is important to note that to characterize the concept of "professional and pedagogical readiness》, scientists use the concept of "professional competence», which is defined as professional readiness and the ability of the subject of labor to perform tasks and responsibilities of everyday activities.

The result of preparing future teachers for professional activity is a certain level of readiness for professional activity, an active state of the personality, covering a positive attitude to the profession, abilities, knowledge, skills, stable professionally important qualities. 
The professional readiness of the future teacher of a foreign language for pedagogical activity is characterized by his professional qualifications and a certain combination of personal qualities and properties.

It is worth noting that the organization in higher education institutions of the professional training of future teachers of a foreign language has certain features based on an integrated approach to ensuring the content of the educational process.

A definitive analysis of the concept of «professional and pedagogical training of future teachers of a foreign language» suggests that the result of this process is general cultural, professional, psychological and pedagogical, linguistic, methodologically technological preparation, which is an important condition for ensuring the quality and productivity of educational, practical and educational components of specialized training for high school students.

Key words: future teacher of a foreign language, professional and pedagogical training, professional competence, readiness, professional readiness, training, education, pedagogical process.

УДК 373.2.015.31:172.15

DOI https://doi.org/10.31392/NPU-nc.series5.2019.71.64

Якименко С. I.

\section{ПІДГОТОВКА МАЙБУТНІХ УЧИТЕЛІВ ПОЧАТКОВОЇ ОСВІТИ ДО НАСТУПНОСТІ ФОРМУВАННЯ НАЦІОНАЛЬНО-ПАТРІОТИЧНОЇ САМОСВІДОМОСТІ СТАРШИХ ДОШКІЛЬНИКІВ ТА МОЛОДШИХ ШКОЛЯРІВ}

Розглядаються питання підготовки вчителів початкової освіти до наступності формування національно-патріотичної самосвідомості старших дошкільників та молодших школярів.

У вихованні патріота велика роль відводиться початковій школі. Патріотичне виховання передбачає систематичну підготовку особистості до суспільного життя в умовах демократії та поєднує в собі громадянські знання та готовність особистості брати участь у суспільному житті країни, патріотичні чесноти-норми, установки, иінності та якості, притаманні патріоту демократичного суспільства. Виховувати свідомого патріота означає формувати в учня комплекс особистих якостей і рис характеру, щзо є основою специфічного способу мислення та спонукальною силою повсякденних дій, вчинків, поведінки. Це патріотична самосвідомість, громадянська відповідальність, мужність, повага до Конституиії, законів Української держави, досконале знання державної мови, повага до батьків, свого родоводу, до традиџій, дисииплінованість, працьвовитість, піклування про природу, фізична досконалість, моральна чистота, висока художньо-естетична вихованість.

Патріотичне виховання особистості здійснюється шляхом системної організації навчальної, соиіальної та суспільно-корисної діяльності, спрямованої на дотримання прав та обов'язків громадянина. Становлення патріотичної компетентності особистості пов'язано з формуванням базових иінностей української та світової культури, які визначають ї̈ патріотичну самосвідомість. Формування патріотичних иіннісних орієнтирів трунтується на соиіокультурних досягненнях багатонаціонального народу, народів інших краӥн, культурних та історичних традицій рідного краю. Патріотичне виховання молодших школярів у сучасній початковій школі повинно здійснюватися на засадах системного підходу відповідно до вікових і пізнавальних можливостей учнів. Підгрунтям для патріотичного виховання є політичне, правове та моральне виховання, щчо реалізується шляхом організації навчальних занять, проведення позакласної роботи та створення відповідного демократичного середовища, формування сочіальної та комунікативної компетентності у навчально-виховному процесі. Зміни акиентів у суспільній свідомості зумовлюють зміну вимог у педагогічній освіті. Тому важливим у контексті дослідження проблеми підготовки майбутнього вчителя до патріотичного виховання молодших школярів вважаємо сформованість патріотичності в майбутніх учителів.

Ключові слова: старші дошкільники, молодші школярі, вчитель, освіта, виховання, навчання, самосвідомість, наступність.

Суверенній Україні потрібні громадяни, які мають глибоко усвідомлену життєву позицію. Виховати таких особистостей можна за умови розвитку національної освіти, в якій система виховання та навчання грунтується на ідеях народної філософії, засадах української етнопедагогіки, народознавства, основах християнської релігії, наукової педагогічної думки, родинного виховання тощо.

Однією із нагальних потреб сучасного українського суспільства $є$ формування у молодого покоління національно-патріотичних почуттів, активної життєвої позиції й соціальної відповідальності. Ефективність цього процесу зростає за умови залучення школи та сім'ї, які є найважливішими суб'єктами виховання. Успішне здійснення виховання старших дошкільників та молодших школярів передбачає глибоке знання вчителями початкової школи і врахування в своїй роботі вікових та індивідуальних особливостей, тенденцій розвитку школярів в сучасних умовах, які вимагають формування громадянина, патріота правової, демократичної держави. Актуальним є необхідність виховання гуманних почуттів: любові до людини, поваги і піклування про неї, доброти, співчуття, великодушності, толерантності тощо.

Патріотичне виховання - це один із складників системи гармонійного розвитку дошкільника. Базисом національно-патріотичного виховання є певна сума знань, окреслена Базовим компонентом дошкільної освіти в Україні. Чинна програма економічної і соціальної розбудови Української держави має блок завдань, спрямованих на розвиток освіти і виховання підростаючого покоління. Одним із пріоритетних проявів цих 